\title{
Normal tear protein profiles and age-related changes
}

\author{
J. I. McGILl, ${ }^{1}$ G. M. LIAKOS, ' N. GOULDING, ${ }^{2}$ AND D. V. SEAL ${ }^{3}$ \\ From the 'Southampton Eye Hospital, the ${ }^{2}$ Department of Microbiology, Southampton Medical School, \\ and the ${ }^{3}$ Division of Communicable Diseases, Clinical Research Centre, Harrow, Middlesex
}

SUMmaRY The specific and non-specific tear proteins have been analysed by means of the ELISA technique to establish the normal and age-related values. There is a linear and related decline of lysozyme and lactoferrin with age, and a similar but unrelated reduction in tear volume. IgA levels gradually decline, while caeruloplasmin and IgG both increase after the fifth decade. The results suggest that tear IgG and caeruloplasmin are probably transudates from the serum, that $\operatorname{IgA}$ is secreted independently of tear volume, and that lysozyme and lactoferrin are secreted at the same site but independently of tear volume.

The chemical composition of human tears is complex, as they contain lipids, proteins, and other elements dissolved in fluid secretions of the lacrimal gland. The protective properties of the protein fractions in health and disease have long been appreciated, but only recently has their enormous complexity become apparent. At least 60 components of the tear protein fraction have been demonstrated, ' among them the specific and non-specific immunoglobulins. These form the first line of defence against an external infection and seem to be more effective than the systemically produced antibodies. ${ }^{2} \mathrm{IgA}$ is secreted in tears, ${ }^{3}$ being locally produced in the lacrimal gland, and differs chemically and immunologically from its serum counterparts. ${ }^{4}$

The non-specific proteins include lactoferrin and lysozyme secreted by the lacrimal acinar cells ${ }^{56}$ and known to inhibit bacterial multiplication. Different estimates of their concentration have been reported. Lactoferrin, one of the major tear proteins, ${ }^{1}$ was first identified in tears in $1966,{ }^{7}$ but little is known of how the levels alter in disease, except that there is a reduction in the dry eye patient. Similarly, caeruloplasmin, a glycoprotein carrying copper, has been identified in tears by immunoelectrophoresis ${ }^{8}$ and by the use of monospecific antisera, ${ }^{3}$ but it has not yet been determined how age or ocular disease affects these levels. Furthermore, a combined or simultaneous study of the specific and non-specific tear

Correspondence to James I. McGill, FRCS, Southampton Eye Hospital, Wilton Avenue, Southampton SO9 4XW. proteins has not yet been carried out, either in the normal eye or in various external eye diseases. Thus, there is a need to establish an accurate estimate of these protein concentrations. We have done this by means of the enzyme-linked immuno-assay (ELISA) method. ${ }^{9}$

The purpose of our study has been to measure the normal concentrations of the immunoglobulins $\operatorname{IgA}$ and IgG and the tear proteins lysozyme, lactoferrin and caeruloplasmin. Our findings have been compared with those of other reports where different techniques were used. Secondly, we wished to establish for the first time the normal concentration of lactoferrin and caeruloplasmin, and thirdly we wished to determine whether age-related changes occur in the tear film protein components other than lysozyme.

\section{Material and methods}

Selection of subjects. Fifty-five subjects were selected for this study; their ages varied from 20 to 82 , covering the different age groups equally. The majority of them had no ocular history, but a few cases with macular degeneration were included in the older age groups.

Collection of specimens. Tear fluid was collected on Whatman no. 1 filter paper discs, $5 \mathrm{~mm}$ in diameter, which were placed in the lower fornix of the unanaesthetised eye. "1 The volume of tears collected was determined by weighing the paper discs in their bottles before and after collection. Every effort was 
made to avoid injuring the ocular tissues, thus inducing excess lacrimation.

Assay of proteins. The concentrations of $\operatorname{IgA}, \operatorname{IgG}$, lysozyme, lactoferrin, and caeruloplasmin in the tear fluid collected were estimated by ELISA ${ }^{9}$ with tear eluates collected as neat tears on filter paper discs to which phosphate buffered saline was added."

Tear volume. This was estimated by the modified Schirmer's test" in the unanaesthetised eye by measuring the length of filter paper wetted over 5 minutes which had been placed in the lower fornix. A modified version of Schirmer's I test was used, whereby the Schirmer strip was moved to another site within the lower fornix if wetting had not occurred after 2 minutes.

\section{Results}

The mean concentrations of the tear proteins for each decade are shown in Table 1 . The age-related changes

Table 1 Mean normal values of tear protein concentrations for each decade in $\mathrm{mg} / \mathrm{dl}$

\begin{tabular}{lllllll}
\hline Age & $20-29$ & $30-39$ & $40-49$ & $50-59$ & $60-69$ & $70-$ \\
& 18 eyes & 18 eyes & 18 eyes & 18 eyes & 17eyes & 19 eyes \\
\hline Lactoferrin & 136 & 139 & 118 & 90 & 114 & 87 \\
& $(26)$ & $(18)$ & $(24)$ & $(22)$ & $(32)$ & $(22)$ \\
Lysozyme & 110 & 105 & 99 & 79 & 73 & 72 \\
& $(22)$ & $(18)$ & $(20)$ & $(16)$ & $(24)$ & $(28)$ \\
Caeruloplasmin & 12 & 13 & 10 & 15 & 15 & 30 \\
& $(2)$ & $(2)$ & $(0 \cdot 8)$ & $(4)$ & $(2)$ & $(14)$ \\
IgA & 52 & 63 & 41 & 41 & 52 & 45 \\
& $(14)$ & $(14)$ & $(12)$ & $(12)$ & $(24)$ & $(14)$ \\
IgG & $1 \cdot 7$ & $0 \cdot 7$ & $0 \cdot 7$ & $0 \cdot 7$ & $2 \cdot 8$ & $6 \cdot 5$ \\
& $(1 \cdot 0)$ & $(0 \cdot 2)$ & $(0 \cdot 4)$ & $(0 \cdot 2)$ & $(2 \cdot 2)$ & $(22)$ \\
\hline
\end{tabular}

Numbers in parentheses are standard deviations.

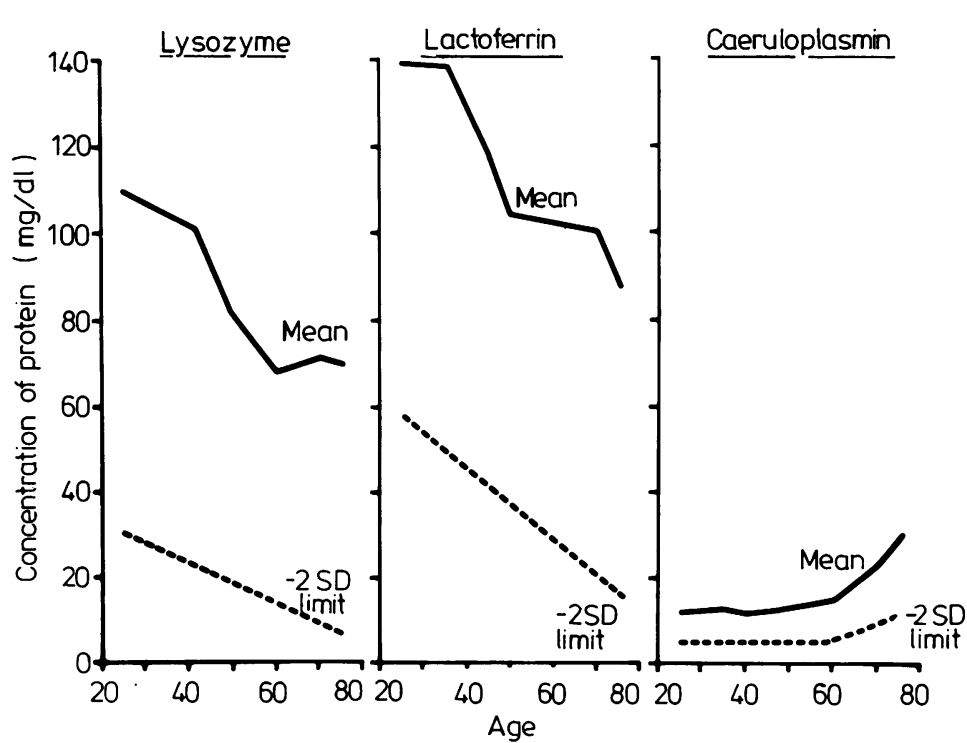

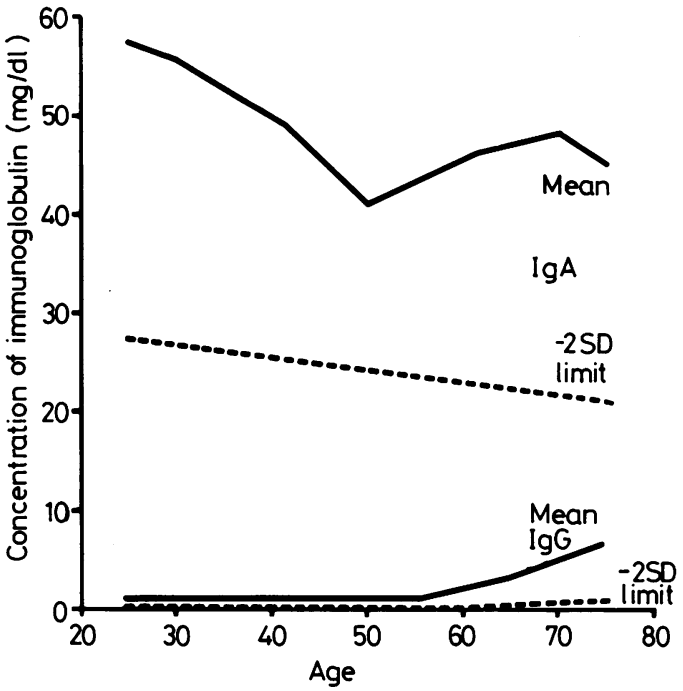

Fig. 1 Age-related changes of the immunoglobulins IgA and $\operatorname{Ig} G(110$ eyes).

of the specific immunoglobulins (Fig. 1) and nonspecific antibacterial proteins are given (Fig. 2). Lysozyme and lactoferrin declined by a similar amount, $1 \mathrm{mg} / \mathrm{dl}(10 \mathrm{mg} / \mathrm{l})$ for every year, linearly and progressively with age. IgG and caeruloplasmin levels remained static until an apparent increase after the fifth decade, while IgA levels only fell slightly with age. Tear flow, as measured by the modified Schirmer's test on the open eye, declined steadily after the age of 40 (Fig. 3), when there was then significant correlation $(r=-0.8)$ between decreased flow and increasing age.
Fig. 2 Age-related changes of lysozyme, lactoferrin, and caeruloplasmin (110 eyes for each protein). 


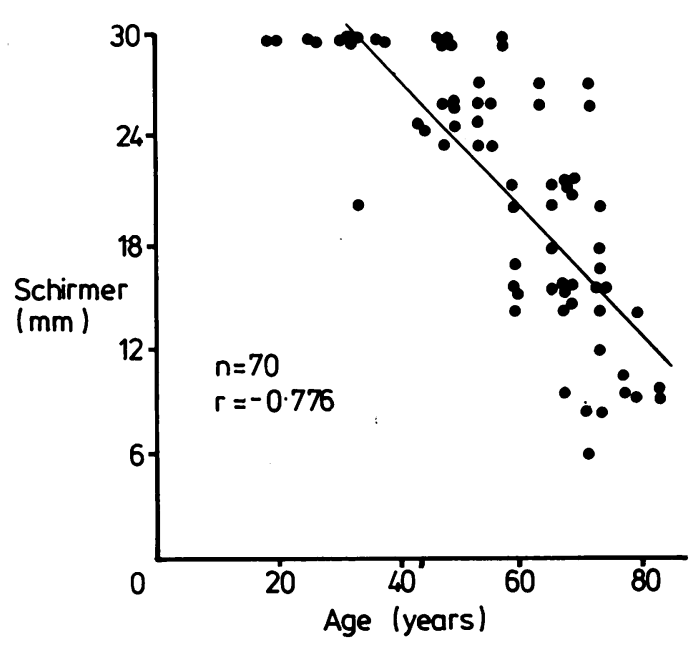

Fig. 3 Relationship between the modified Schirmer's test and age, showing that there is a linear decline in tear production in the normal subject after the age of 40.

The correlation of one protein with another illustrates how the concentrations of one protein relate to those of the other. A positive correlation signifies that the concentrations of the 2 behave similarly in different subjects, while a negative correlation signifies that the concentrations alter in opposite directions.

There was a strong positive correlation between lysozyme and lactoferrin (Fig. 4) and between IgG and caeruloplasmin (Fig. 5). Both lysozyme and lactoferrin showed a negative correlation to IgG and caeruloplasmin, with IgA showing no significant correlation to any of the proteins (Table 2).

In relation to age, lysozyme and lactoferrin showed a negative correlation, as their concentrations declined with age, IgG and caeruloplasmin a positive one, and $\operatorname{IgA}$ no significant correlation. It thus emerged that lysozyme and lactoferrin formed one group of similarly behaving proteins (Fig. 4) and IgG and caeruloplasmin another (Fig. 5), but each group behaved in an opposite way to the other. IgA behaved independently. No significant correlation could be found between tear volume collected on the discs and any of the proteins, except in the last 2 decades of life

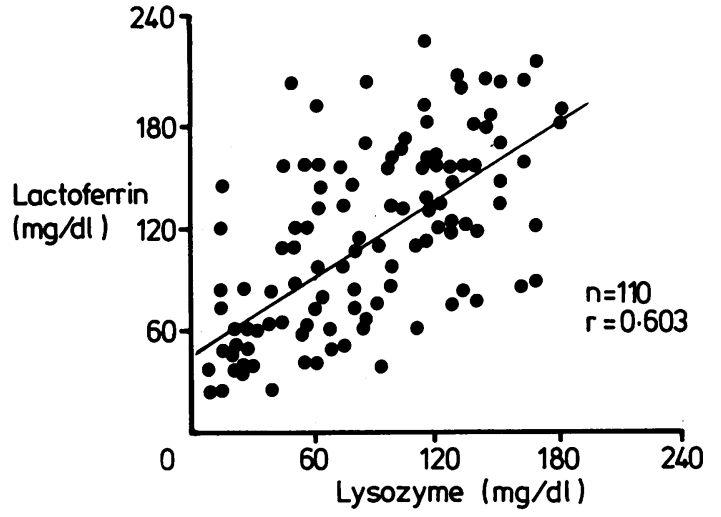

Fig. 4 Showing linear relationship between lysozyme and lactoferrin concentration changes.

$(60-69,70-79)$, when tear volume decreased and the concentrations of caeruloplasmin $(r=-0 \cdot 33)$ and IgG $(r=-0 \cdot 3)$ increased.

\section{Discussion}

This work has established the concentrations of various specific and non-specific tear proteins and, more importantly, has shown how these values in some instances alter quite appreciably with age.

There is general agreement that $\operatorname{IgA}$ is the predominant tear immunoglobulin, but the reported concentrations have varied considerably in relation to the technique used. Our values of $40 \mathrm{mg} / \mathrm{dl}$ at the age of 50 are higher than those obtained by somefor example, $14 \mathrm{mg} / \mathrm{dl},{ }^{12} 20 \cdot 6 \mathrm{mg} / \mathrm{dl},{ }^{13}$ and $24 \cdot 6 \mathrm{mg} / \mathrm{dl}^{14}$ -but are comparable to others-e.g., $36 \cdot 8 \mathrm{mg} / \mathrm{dl}^{15}$ (SI conversion: $\mathrm{mg} / \mathrm{dl} \times 10=\mathrm{mg} / \mathrm{l}$.) Only one group has measured the concentration at different ages and found that IgA levels seem to be higher in younger and older people. ${ }^{14}$ Our findings are comparable, showing a small decrease in the 40-49 and the 50-59 age groups, and then a small rise in the older groups but still lower than the younger ones. Our method of measuring $\operatorname{IgA}$ in tear eluates, as opposed to neat tears, has proved satisfactory.

Most reports agree that IgG tear levels are low. ${ }^{316}$ Some, though, have found it in equal quantities to

Table 2 Correlation coefficients between each tear protein measured

\begin{tabular}{|c|c|c|c|c|c|}
\hline & Age & Lactoferrin & Lysozyme & Caeruloplasmin & $\lg A$ \\
\hline Lactoferrin & $-0 \cdot 368^{*}$ & - & - & - & - \\
\hline Lysozyme & $-0.417^{*}$ & $0.603^{*}$ & - & - & - \\
\hline Caeruloplasmin & $0 \cdot 326$ & $-0 \cdot 234$ & $-0 \cdot 280$ & - & - \\
\hline $\operatorname{Ig} A$ & $-0 \cdot 121$ & 0.098 & 0.082 & $0 \cdot 104$ & - \\
\hline IgG & $0 \cdot 270$ & $-0 \cdot 271$ & -0.298 & $0.841^{*}$ & 0.043 \\
\hline
\end{tabular}

*Significant to $\mathrm{p}<0 \cdot 01$. 


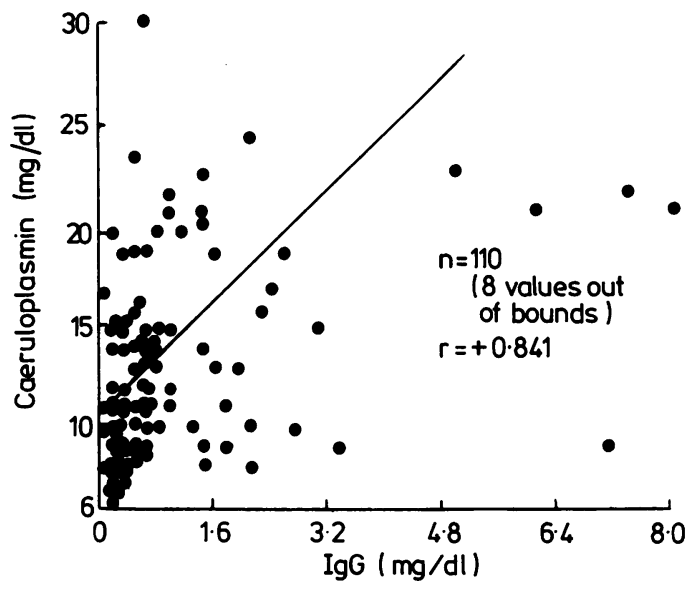

Fig. 5 Showing relationship between $\operatorname{IgG}$ and caeruloplasmin concentrations.

IgA, ${ }^{12}{ }^{13}$ while others ${ }^{17}$ have found the concentration to be much higher at $79 \mathrm{mg} / \mathrm{dl}$. This is more than 3 times the concentration of IgA as measured by the same authors. It is likely that these high values are the result of using incompletely absorbed antisera in the technique of detecting the specific immunoglobulins, so that there was significant cross-reaction, with $\operatorname{IgA}$ being measured as IgG. Our mean age-adjusted value was $2 \mathrm{mg} / \mathrm{dl}$, but in some cases there was an increased concentration in the older group. The most likely explanation is increased concentration due to reduced tear flow. This is confirmed by the finding of a similar concentration increase in caeruloplasmin, known to be formed by hepatocytes. ${ }^{18} \mathrm{~A}$ ratio between IgG and caeruloplasmin thus has useful potential, particularly in tear evaporation states seen clinically.

Lysozyme, perhaps the most widely investigated tear protein, has been estimated by the lysozyme/agar plate" with hen egg lysozyme standards. We found a mean age-adjusted value of $100 \mathrm{mg} / \mathrm{dl}$, using a human lysozyme standard, which compares with higher values of $170 \mathrm{mg} / \mathrm{dl}$ found with the lysoplate method ${ }^{19}$ and $130 \mathrm{mg} / \mathrm{dl}$ by a less sensitive and less accurate immunoassay method. ${ }^{20}$ We found that lysozyme levels started falling after the age of 40 at a rate of decrease of $1 \mathrm{mg} / \mathrm{dl}$ per year of age, with the same rate of decline as that for lactoferrin. Conflicting reports exist as to the effect of age on lysozyme levels, some reporting no change, ${ }^{21}$ while others give a gradual decline with age. ${ }^{11192022}$ Those workers who cannot detect a decreasing concentration with age are likely to be using an insensitive method.

Lactoferrin levels were found to have a mean ageadjusted value of $140 \mathrm{mg} / \mathrm{dl}$, confirming the work of Broekuyse, ${ }^{23}$ and, just like lysozyme, it declines steadily with age at $1 \mathrm{mg} / \mathrm{dl}$ per year. The similarity between lactoferrin and lysozyme in terms of concentration and decline with age was impressive. In spite of their different molecular weights $(75000$ for lactoferrin and 15000 for lysozyme), both are identified within the same molecular range, ${ }^{1}$ have low serum levels ${ }^{324}$ and a similar production site, identified as the acinar epithelial cells of both the main and the accessory lacrimal tissues. ${ }^{56}$ Both have antibacterial properties ${ }^{2526}$ have a strong positive correlation to each other in terms of their concentration, and decline at the same rate with age. It is therefore logical to expect that a pathological reduction of tear secretion, such as in dry eyes, results in decreased levels not only of lysozyme but also of lactoferrin. Other workers have found decreased lysozyme levels in dry eyes ${ }^{112127}$ as well as decreased lactoferrin levels. ${ }^{28}$ It thus appears that the measurement of both lactoferrin and lysozyme will represent useful diagnostic tests in dry eye investigations. This has already been suggested in a recent study of tear lactoferrin. ${ }^{29}$

The role and concentration of caeruloplasmin in tears has so far not been determined. We found a mean age-adjusted value of $16 \mathrm{mg} / \mathrm{dl}$, with a marked increase with age over 70 years, in a few cases. As with IgG, this apparent increase with advancing age might be due to increased concentration.

It was interesting that there was a significant positive correlation between IgG and caeruloplasmin, suggesting a common source of origin, different from that of lysozyme and lactoferrin, with which there was a negative correlation. Both have probably been secreted from serum, either by the lacrimal gland or via the conjunctiva, and suggests that the blood-tear protein barrier is incomplete, allowing a small leakage of serum protein to occur.

There are still a large number of tear proteins that remain to be studied and quantified before the defensive mechanism of the tears against external infection is fully understood. We have estimated the concentration of 5 tear proteins and, by so doing, hope to be able to evaluate their significance in pathological states. Expressing protein concentrations in ratios between each other magnifies changes that occur in either of the proteins expressed, and offers a more sensitive and accurate method of investigating pathological changes in various ocular disorders. Now that these normal and age-adjusted values of the tear proteins have been established, it will be possible to study their significance in various ocular disorders.

We thank the Research Committec of the Wessex Regional Health Authority (grant to N.J.G.) and the British National Committce for the Prevention of Blindness (grant to J.M. and G.M.L.) for grants to enable this work to be carricd out. We also thank Professor Peter Watt, Department of Microbiology, University of Southampton, for much valuable advice as well as laboratory facilitics. 


\section{References}

1 Gachon AM, Verrelle P, Betail G, Dastuguc B. Immunological and electrophoretic studies of human tear proteins. Exp Eye Res 1979; 29: 539-53.

2 Knoph H, Blaklow N, Glassman M, Cline W, Wong V. Antibody in tears following intranasal vaccination with inactivated virus. III. Role of tear and serum antibody in experimental vaccinia conjunctivitis. Invest Ophthalmol Visual Sci 1971; 10: $760-7$.

3 Sapse AT, Bonavida B, Stone W, Sercarz EE. Proteins in human tears. I. Immunoelectrophoretic patterns. Arch Ophthalmol 1969; 81: 815-9.

4 Tomasi T, Tan E. Solomon A, Prendergast R. Characteristics of an immune system common to certain external secretions. J Exp Med 1965; 121: 101-8.

5 Allen M, Wright P, Reid L. The human lacrimal gland. Arch Ophthalmol 1972; 88: 493-7.

6 Gillette TE, Allansmith MR. Lactoferrin in human ocular tissues. Am J Ophthalmol 1980; 90: 30-7.

7 Masson PL, Heremans JF, Schonne E. Lactoferrin, an iron binding protein in neutrophilic leucocytes. J Exp Med 1969; 130: 643-58.

8 Josephson AS, Lockwood DW. Immuno-electrophoretic studies of the protein components of normal tears. J Immunol 1964; 93: $532-9$.

9 Goulding N, Scal DV, Liakos GM, McGill JI. Quantitative estimation of human tcar proteins by enzymc-linked immunoabsorbent assay. BrJ Ophthalmol in press.

10 Seal DV, Mackic IA, Coakes RL, Faroogi B. Quantitative tear lysozyme assay: a new technique for transporting specimens. $\mathrm{Br} J$ Ophthalmol 1980; 64: 700-4.

11 Mackie IA, Seal DV. The questionably dry eye. BrJ Ophthalmol 1981; 65: 2-9.

12 McClellan BH, Whitney CR, Newman LP, Allansmith MR. Immunoglobulins in tears. Am J Ophthalmol 1973; 76: 89-100.

13 Tragakis M, Economidis I, Pollalis S, Gartaganis S. The tear immunoglobulin levels in normal persons and in patients with staphylococcal, trachomatous and allergic diseases. In: TrevorRoper P, ed. VIth Congress of European Society of Proceedings of the Ophthalmology. London: Academic Press and Royal Society of Medicine, 1980: 40: 281-5.

14 Sen DK, Sarin GS, Mani K, Saha K. Immunoglobulins in tears of normal Indian people. Br J Ophthalmol 1976; 60: 302-4.

15 Little JM, Centifanto YM, Kaufman HE. Immunoglobulins in human tears. Am J Ophthalmol 1969; 68: 898-905.

16 Bluestone R, Easty DL, Goldberg LS, Jones BR, Pettit TH. Lacrimal immunoglobulins and complement quantified by counter-immunoelectrophoresis. Br J Ophthalmol 1975; 59: 279-81.

17 Bazzi C, Cattaneo R, Migone V, Farina M. Further observations on immunoglobulines of external secretions. Prog Immunobiol Stand 1970; 4: 333-8.

18 Evans GW. Copper homeostasis in the mammalian system. Physiol Rev 1973; 53: 535-70.

19 Bonavida B, Sapse AT. Human tear lysozyme. II. Quantitative determination with standard Schirmer strips. Am J Ophthalmol 1968; 66: 70-5.

20 Sen DK, Sarin GS. Immunoassay of human tear lysozyme. Am J Ophthalmol 1980; 90: 715-8.

21 Avisar R, Menache R, Shaked P, Rubinstein J, Machtey I, Savir H. Lysozyme content of tears in patients with Sjögren's syndrome and rheumatoid arthritis. Am J Ophthalmol 1979; 87: 148-51.

22 Pietsch RL, Pearlman ME. Human tear lysozyme variables. Arch Ophthalmol 1973; 90: 94-6.

23 Broekuyse RM. Tear lactoferrin: a bacteriostatic and complexing protein. Invest Ophthalmol Visual Sci 1974; 13: 550-4.

24 Bennett RM, Mohla C. A solid phase radio-immunoassay for the measurement of lactoferrin in human plasma. Variations with age, sex and disease. J Lab Clin Med 1976; 88: 156-61.

25 Liotet S, Cohen N, Sainte-Laudy J. Un antibiotique naturel des larmes: la lactotransferrine. J Fr Ophtalmol 1980; 3: 159-63.

26 Harad M, Miyata M, Ishikawa $S$. Antibacterial substances in human tears. Jpn J Ophthalmol 1980; 24: 320-7.

27 Van Bijsterveld OP. Diagnostic tests in the sicca syndrome. Arch Ophthalmol 1969; 82: 10-4.

28 Liotet S, Hamard H, Beranger A, Arrata M. Etude des proteines lacrymales au cours des syndromes secs. J Fr Ophtalmol 1980; 3: 263-7.

29 Kijlstra A, Jenrissen SHM, Koning KM. Lactoferrin levels in normal human tears. Br J Ophthalmol 1983; 67: 199-202. 